\title{
The Knowledge of Local Labor Market as a Determinant of Anti-Unemployment Counteraction
}

\author{
Błażej Balewski \\ Higher School of Personnel Management in Konin, Konin, Poland
}

\begin{abstract}
Purpose: Indicating possible options for the development of local labor markets by eliminating inefficient implementation of employment policies and knowing separate entities of local labor markets based on assumptions of one of the marginal schools (doctrines). Design/Methodology/Approach: This research was based on a method called systematic review, and foregoing the author's research. Findings: Recognizing the possible existence of opportunities for local labor markets and reducing the unemployment by exploring the differences between those markets on the basis of Neo-Austrian school's assumptions. Research limitations/implications: Implications that will help eradicate or at least significantly reduce the ineffective state intervention in the labor market and by learning and intensification of the strong sides separate for each of the labor markets, will help reduce the local unemployment rates. Practical implications: Promoting the idea of non-intervention of the state in the labor market in pursuit of their active labor market policies and promoting the use of the Neo-Austrian school's economic assumptions in order to achieve the possible development of local labor markets and reduction of the unemployment rate.
\end{abstract}

Keywords: unemployment, government policy, unemployment counteraction, effectiveness, market policy

An attempt of practical implementation of the idea of unemployed economization activation within the labor market active policy realized by local government (Balewski, 2006, p. 3) seems as an ineffective journey toward it what is knowable and really existing - namely "ideas". It comes through its name, definition, images, descriptions, and mental knowledge (Krokiewicz, 1958) about interpreted phenomenon. An attempt of an issue redefining or the way of development indication, making use from economic assumptions of marginal schools, seems to be justified in order to prevent unemployment.

\section{The Effectiveness of the Labor Market Policy}

Drawing inter alia from Hegel's opinion that “(...) the state is the realization of freedom, absolute ultimate goal, (...) all value that a man has, all spiritual reality he has only through the state (...)" (Hegel, 1837), attempts of proving that three elements model of economic life: Household + company + state is a model which can be efficient system is an issue that is an object of the study for many economists and socio-economic life practitioners (Kołodziejczyk, 1995; Wiśniewski, 2005).

An employment policy, since its inception in the early 20th century, has been repeatedly redefined (see Table 1).

Corresponding author: Błażej Balewski, Ph.D., Dean of Economic Faculty, Higher School of Personnel Management in Konin, Konin, Poland; research fields: HRM effectiveness, employment policy, labor market, and unemployment counteraction. E-mail: blazej@balewski.pl. 
Table 1

Chosen Approaches to Employment Policy

\begin{tabular}{|c|c|}
\hline Author & Character and functions of employment policy \\
\hline B. Winiarski & $\begin{array}{l}\text { "(...) state authorities actively influence the labor market taking into consideration the needs of the } \\
\text { country's economy and reconciling the interests of employers and workers". }\end{array}$ \\
\hline M. Sęp & $\begin{array}{l}\text { "(...) in a dynamic system, employment policy establishes and clarifies the power which governs the } \\
\text { correlation between economy development process and demographic and social processes. The policy } \\
\text { indicates some defined employment goals, as well as methods, measures, and paths leading to achieving } \\
\text { these goals. Thus, it influences employment". }\end{array}$ \\
\hline K. Markowski & $\begin{array}{l}\text { "(...) employment policy, as a connection of economic and social policy elements, consists in developing } \\
\text { and implementing employment programmes with some major goals concerning development of the state } \\
\text { economy”. }\end{array}$ \\
\hline Z. Wiśniewski & $\begin{array}{l}\text { "(...) sign of activities aimed at rational allocation of human resources }(\ldots) \text { ".. "(..) that the main goal of } \\
\text { employment policy is maintaining an unemployment rate that the society would be able to accept }(\ldots) \text { ". }\end{array}$ \\
\hline M. Kabaj & $\begin{array}{l}\text { The aims of employment policy (policy counteracting unemployment) are to alleviate the financial burden } \\
\text { of unemployment, periodically activate the unemployed with the means of active forms of employment } \\
\text { promotion (as an integral element of socio-economic policy) and analyse and eliminate the factors that } \\
\text { generate unemployment. }\end{array}$ \\
\hline J. Gogolewska & Employment policy serves social and economic functions. \\
\hline W. Jarmołowicz & $\begin{array}{l}\text { "(...) employment policy should have a local character and it is not equal to labor market policy. } \\
\text { Employment policy is mostly aimed at maintaining the existing jobs and creating new jobs on the } \\
\text { so-called primary market, whereas labor market policy is a part of employment policy which concentrates } \\
\text { on solving structural and social problems in the already existing labor market". }\end{array}$ \\
\hline
\end{tabular}

Note. Source: Balewski (2014).

Synthesis of existing concepts of the employment policy can state that it is a form of state intervention in the labor market in order to introduce the pro-development economic and social change (Balewski, 2014). The policy of the labor market is a special form of it. Because of the implementation way of its economic dimension, labor market policies can be divided into passive and active policies.

Passive labor market policy is a factor which enhances system orderliness without a necessity of every time interference.

In contrast, active labor market policy is a form expected by the people from so-called the highest risk group. This group is a potential source of danger for the state security, including the socio-economic security.

Intervention works, public works, trainings, and labor market instruments which support basic services in the labor market (e.g., internships, covering travel costs to the employer who notifies vacancies, costs of accommodation in the workplace, financing of equipment, legal consulting and advisory costs, refunding the cost social insurance, etc.) (Balewski, 2014) are instruments of active labor market policies in the current Polish normative act which regulates issues in the area of labor market.

All the instruments listed above do five functions: to activate the unemployed, to decrease the level of structural adaptations on the labor market, to increase the productivity of the labor force, to verify the level of activity for work, and to influence the unemployment level (Calmfors \& Skedinger, 1995). Additionally, the "pro-active policy" should support cooperation (Meager, 1998) or the period of time between part-time work to full-time one and flows of information from the educational system to the labor system (Maksim, 2005), and also to propagate the equal chances on the labor market (Maksim, 2005).

According to the main trends in a neoclassical economics mainstream, it is reasonable to understand and implement these mechanisms which increase the level of efficiency such forms of state intervention in the labor market or even their attempt of economization. Active labor market policies construct optimal efficiency measures (see Figure 1). 


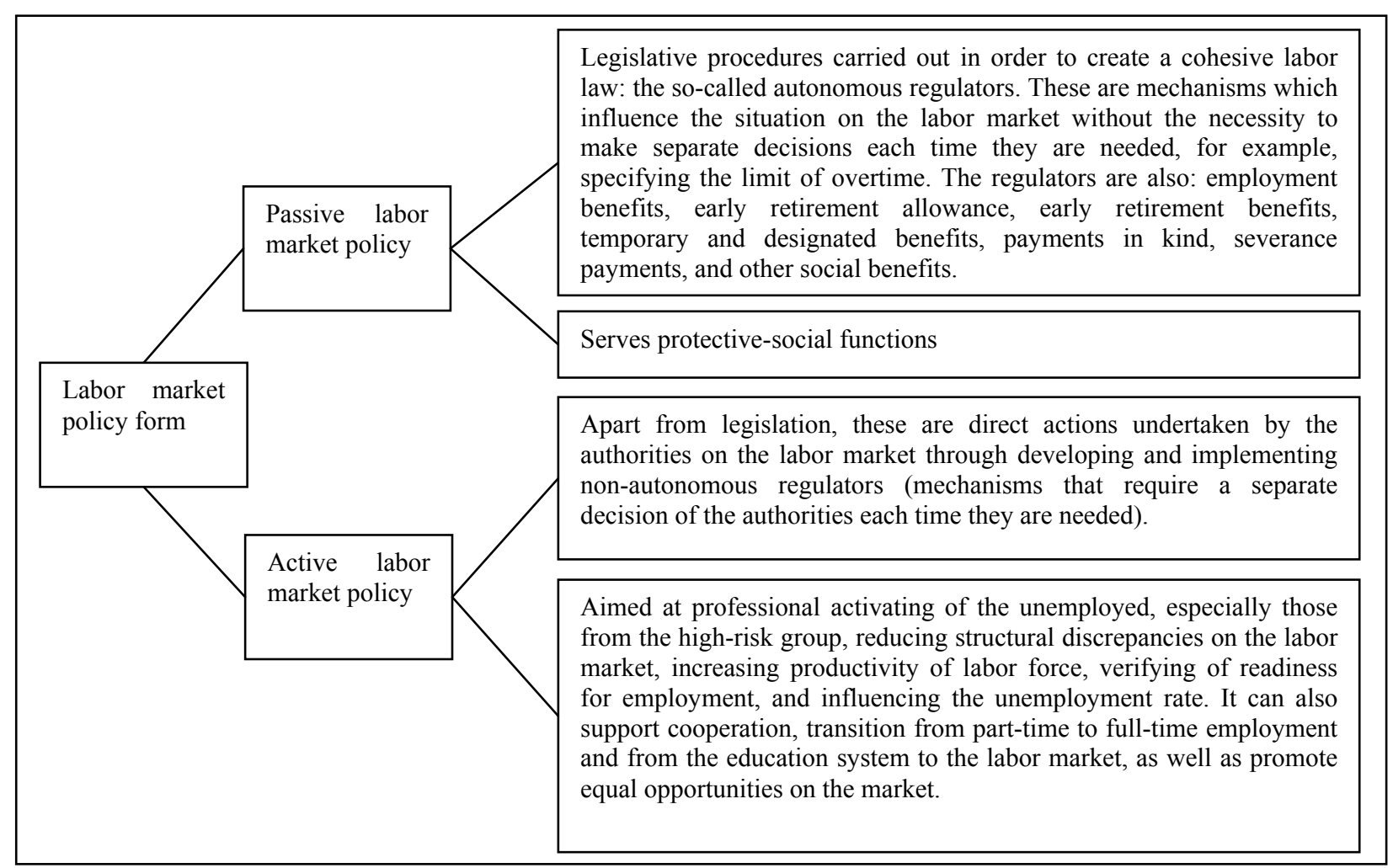

Figure 1. Characteristics of labor market policy forms. Source: Balewski (2014).

Effectiveness of active forms of counteracting unemployment propagated from the beginning of the century (Balewski, 2006, p. 1, p. 3; Balewski \& Bartkowiak, 2006, p. 2; Balewski, 2007; Balewski, 2008; Balewski \& Chomicz, 2009) which shows the relations of the connection of the renewed employment cost of program participants, in the period $n(\mathrm{Gn})$ to discounted cost in the period 0 , in the relation to changes of unemployment ratio in period $\mathrm{n}$ and 0 .

$$
E f=1-\frac{\frac{G n}{G_{0} \times d t(0 \ldots n)}}{\frac{1-\Delta W b_{n}}{1-\Delta W b_{0}}}
$$

Although, it is a manifestation of active labor market policy direction, e.g., reducing the level of entropy in the system, it is not observed in the state intervention of the labor market. Its practical ignorance which reinforces the false belief that "(...) the state is a divine idea as it exists on earth (...)" (Hegel, 1837) leads to a limitation of personal freedom and the free use of property part of production by their owners or households forming consumers and entrepreneurs. This occurs because of the fact that employment services, which represent the state in the context of state intervention in the labor market, do not estimate the size of the potential resource flows in unemployment resulting, inter alia, implemented as a result of their active labor market policies.

The past performance active state policy analysis on the labor market paradoxically indicates that factor which increases potential unemployment surges is the action aimed at the so-called group most at risk without simultaneous consideration of the phenomena occurring in all sectors of the economy for which this group is representative. Therefore, e.g., if by analyzing the processes taking place in the stock of unemployment, the 
employment services deemed as most at risk group the people who are qualified bakers, it is necessary to estimate by them how implementation of the program for a selected group of unemployed impacts on the labor market and what consequences may occur pursuing active state policy for a given profession (e.g., bakers) who so far actively and independently participate in the exchange processes in the labor market (see Figure 2).

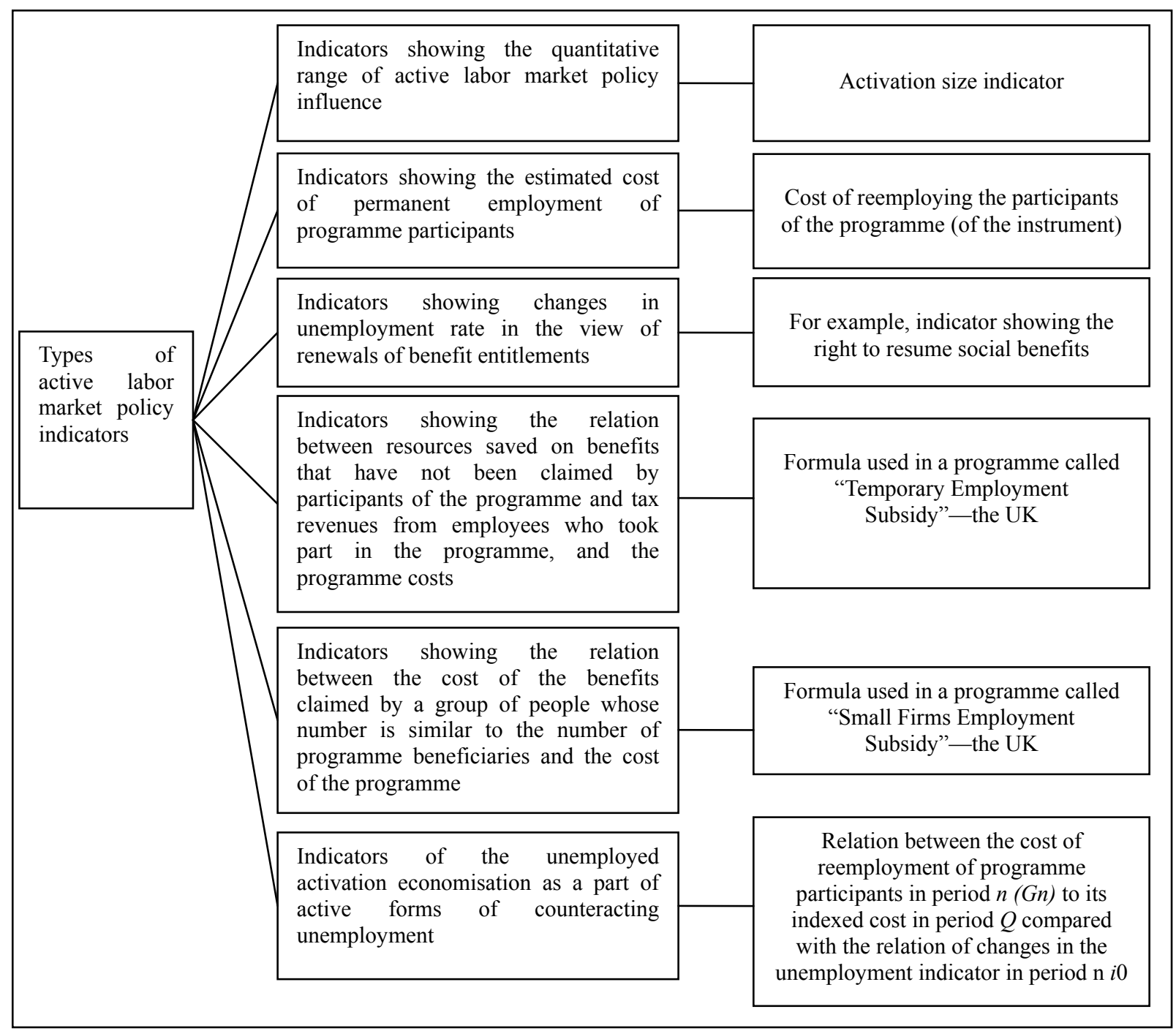

Figure 2. Types of labor market active policy effectiveness indicators. Source: The author's own study on the basis of Balewski (2007, pp. 131-132).

Unfortunately, they show incorrect, synonymous meaning of terms efficiency and efficacy or increasing the semantic category of effectiveness they approach its meaning to the category effectiveness (see Table 2).

If such an analysis indicated the possibility of significant inflow into an unemployment resource and simultaneous reduction of the number of companies in the given industry, it should be included in the process of analyzing the possible implementation of the program in all branches. This, however, due to the existing provisions of the law, is an activity with a high degree of difficulty, or even impossible. Therefore, services are bound to choose that group or groups of significant risk which activation would not affect, or would affect in the slightest way, the inflow to the unemployed resource. Unfortunately, making such analysis by employment 
services remains a postulate which has been unsuccessfully proclaimed by the author for many years (Balewski, 2006; Balewski, 2007; Balewski, 2008).

Table 2

The Statement of Effectiveness Ratios of Intervention Work Programmes

\begin{tabular}{|l|l|l|l|}
\hline Symbol & Ratio's name & Ratio characteristics & Formula \\
\hline G.1. & $\begin{array}{l}\text { The rate of renewed employment of } \\
\text { the intervention work programme } \\
\text { participants }\end{array}$ & $\begin{array}{l}\text { The number of participants who get the full-time job after } \\
\text { intervention work period/the total number of all participants }\end{array}$ & G.1. $=\frac{\text { G.1.1. }}{\text { G.1.2. }}$ \\
\hline G.2. & $\begin{array}{l}\text { The cost of renewed employment of } \\
\text { the intervention work programme } \\
\text { participants }\end{array}$ & $\begin{array}{l}\text { The total subvention cost of the programme/the number of } \\
\text { participants who have got the full-time job after finishing the } \\
\text { program }\end{array}$ & G.2. $=\frac{\text { G.2.1. }}{\text { G.1.1. }}$ \\
\hline G.3 & $\begin{array}{l}\text { The average subvention cost on one } \\
\text { participant of the program }\end{array}$ & $\begin{array}{l}\text { The total subvention cost of the program/the number of the } \\
\text { employed people in the program }\end{array}$ & G.3. $=\frac{\text { G.2.1. }}{\text { G.3.1. }}$ \\
\hline G.4. & $\begin{array}{l}\text { The refusal intervention program } \\
\text { ratio }\end{array}$ & $\begin{array}{l}\text { The number of the unemployed who refused taking part in the } \\
\text { program/the total number of participants in the program }\end{array}$ & G.4. $=\frac{\text { G.4.1. }}{\text { G.4.2. }}$ \\
\hline G.5. & $\begin{array}{l}\text { Maximal using of the subvention } \\
\text { ratio }\end{array}$ & $\begin{array}{l}\text { The average subvention cost per one participant of the program/ } \\
\text { the highest average quota per one participant during the } \\
\text { program }\end{array}$ & G.5. $=\frac{\text { G.3. }}{\text { G.5.1. }}$ \\
\hline
\end{tabular}

Note. Source: Balewski (2007, p. 131).

\section{Instead of Conclusion}

The use of methodological guidance of the marginal school and further attempts to describe the strong and weak points of the labor market seems to be justified in order to limit qualitative and quantitative differences in local labor markets since, appeals for correction of the New Austrian School of Economics as the leading schools are unsuccessful, and part of the universal laws promulgated by representatives of neo-liberal economics has been undermined ${ }^{6}$. Autonomous economic players will be empowered and time-varying and different for different local regularities of development will be shown thanks to the descriptions of local markets, branch markets, and variety of people occurring in a given markets in a space-time.

Further detailed description of the phenomena occurring in local labor markets could also potentially lead to a denial of the occurrence of local labor markets' development, due to:

(1) Consolidation of natural resource unemployment, drawing satisfaction from passive attitude toward work, conditioned by the preference of values which stunt economic growth (Balewski, 2006);

(2) Inability to aggregate comprehensive knowledge essential to control events in the organized structure

\footnotetext{
${ }^{1}$ Where: G.1.1. - the number of persons who got the fulltime employment after finishing all programs; G.1.2.- the number of program participants.

${ }_{2}^{2}$ Where: G.2.1. - the intervention works cost - the sum of all the refunded quotas for all the intervention works organizators, to whom the contract were settled in the mentioned period of time; G.1.1. - as above.

${ }^{3}$ Where: G.2.1. - as above; G.3.1. - it is the total number of hired participants of the program understood as the sum of number of the unemployed hired in particular months, expired in investigation period.

${ }^{4}$ Where: G.4.1.- the number of the unemployed who refused to work in the intervention work program during the investigation period; G.4.2. indicates the number of the taken vacancies of part-time jobs.

Where: G.3.- the average cost of subvention per one employee of the program; G.5.1. - maximal quota of subvention for one participant of the program.

${ }^{6} \mathrm{Cf}$. On the basis of the Phillips curve, it is generally assumed that on the labor market, exists a short-term inversely proportional correlation between a change in the inflation rate and a change in the unemployment rate. Unfortunately, this rule often does not apply to the current flow of goods and money in Poland. This phenomenon has been observed since the beginning of the economic transformation, similarly to the growth of unemployment rate despite an observed decrease in the value of wealth per one employed person. Source: Balewski (2014).
} 
and the use of knowledge gained only in the context of creating the proper environment (Hayek, 1945).

Or it shows that development is a subjectivity and non-existence.

\section{References}

Balewski, B. (2006). Psychosocial and economic effectiveness conditions of active forms of counteracting unemployment. Unpublished PhD thesis. Faculty of Management, University of Economics in Poznań, Poznań.

Balewski, B. (2007). Unemployment counteraction coefficients-The Polish labor market. In D. Kopycińska (Ed.), The policy of the EU member states in relation to labor market competitiveness (pp. 124-138). Chair of Microeconomics, University of Szczecin, Szczecin.

Balewski, B. (2008). Effectiveness indicators of active forms of counteracting unemployment. Education for Safety, University of Security in Poznan, Poznan.

Balewski, B. (2014). Effective unemployment counteraction as a determinant of national security. Journal of US-China Public Administration, 11(11), 884-893.

Balewski, B., \& Bartkowiak, G. (2006). Programy edukacyjne ograniczające bezrobocie na lokalnych rynkach pracy (Educational programs limit unemployment in local labor markets). In A. Barcik and R. Barcik (Eds.), Rozwój lokalny i regionalny (Local and regional development) (pp. 111-124). ATH University of Bielsko-Biała.

Balewski, B., \& Chomicz, W. (2009). Corporate social responsibility and development of renewable resources. In M. Waszkowiak (Ed.), Renewable energy_Energy of the future. Konin: Management Staff for Konin Association.

Calmfors, L., \& Skedinger, P. (1995). Does active labor market policy increase employment?-Technical considerations and some empirical evidence from Sweden. Retrieved from http:/www.ifn.se/wfiles/wp/wp429.pdf

Hayek, F. (1945). The use of knowledge in society. American Economic Review, 35(4), 519-530.

Hegel, G. W. F. (1837). Lectures on philosophy of history: Introduction. Warsaw.

Kołodziejczyk, P. (Ed.). (1995). Analysis of the effectiveness of labor market programs. Warsaw: MPiPS/KUP.

Krokiewicz, A. (1958). Sokrates (Socrates). Warsaw: PAX Publishing House.

Maksim, M. (2005). Aktywna polityka rynku pracy w krajach Unii Europejskiej. Ewolucjakoncepcji-instrumentyifinansowanie (Active labor market policies in the European Union. Evolution concept-The instruments and financing). In A. Pocztowski (Ed.), Praca i zarzqdzanie kapitałem ludzkim w perspektywie europejskiej (Work and management of human capital in a European perspective). Cracow: Oficyna Ekonomiczna.

Meager, N. (1998). Transitional labor markets: Bridges between dependent and self employment. In H. Schwedler (Ed.), New institutional arrangements in the labor market: Transitional labor markets as a new full employment concept. Berlin: European Academy of the Urban Environment.

Wiśniewski, Z. (2005). Europejska strategia zatrudnienia, a polityka rynku pracy (The European employment strategy and labor market policy). In A. Pocztowski (Ed.), Praca i zarzqdzanie kapitałem ludzkim w perspektywie europejskiej (Work and management of human capital in a European perspective). Cracow: Oficyna Ekonomiczna.

Zieleniewski, J. (1981). Organizacja i zarzadzanie (Organization and management). Warsaw: PWN. 